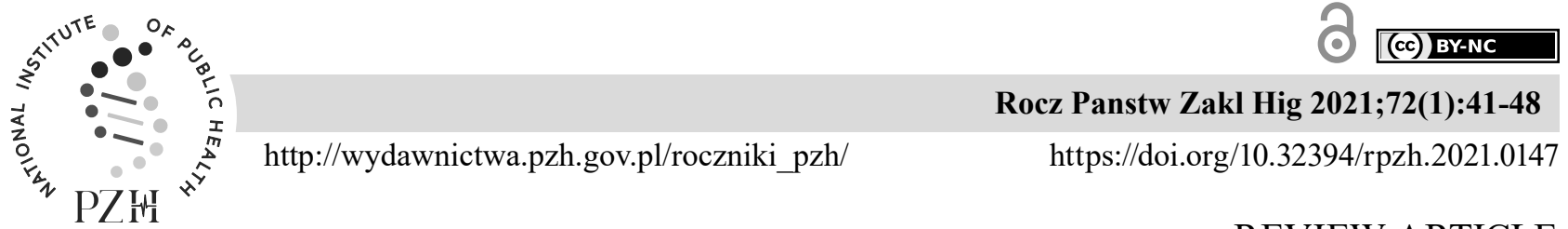

REVIEW ARTICLE

\title{
ENVIRONMENTAL NOISE, ITS TYPES AND EFFECTS ON HEALTH
}

\author{
Andrzej Magiera ${ }^{l}$, Jolanta Solecka ${ }^{l}$ \\ ${ }^{1}$ National Institute of Public Health - National Institute of Hygiene, \\ Department of Environmental Health and Safety, Warsaw, Poland
}

\begin{abstract}
Noise can be defined as an undesirable sound that pollutes the environment. If noise is continuous and exceeds certain levels, negative effects on health can be observed. In recent years, the impact of environmental noise (road traffic noise, railway traffic noise, air traffic noise and industrial noise) on human health has come under increasingly intense scrutiny. Noise can cause a number of negative effects on health that directly or indirectly affect humans. The occurrence of some certain and harmful health effects drives the onset of others and may contribute to the development of various diseases. Health is not only a state of physical well-being, but also mental well-being. Mental health primarily depends on the quality of life, which can be affected by various environmental factors, such as noise. An important aspect of fighting noise is the most effective protection of the population by avoiding sources of noise and reducing it. This can be achieved by introducing new technical solutions and new technologies, including devices that generate less noise. Another important measure is educating the society and influencing the change of individual and collective behavior, which may contribute to reducing the harmful factor, which is noise in human life, and minimize the resulting negative effects on health.
\end{abstract}

Key words: sound, environmental noise, health aspects

\section{STRESZCZENIE}

Hałas jest to dźwięk niepożądany stanowiący zanieczyszczenie środowiska. Jeśli hałas występuje stale i przekracza ustalone poziomy można zaobserwować negatywne skutki zdrowotne. W ostatnich latach zaczęto badać coraz częściej wpływ hałasu środowiskowego (hałas drogowy, kolejowy, lotniczy czy przemysłowy) na zdrowie ludzi. Hałas może powodować szereg negatywnych skutków zdrowotnych, które działają na człowieka pośrednio lub bezpośrednio. Wystąpienie niektórych negatywnych i szkodliwych efektów zdrowotnych wpływa na pojawianie się kolejnych i może przyczyniać się do rozwoju różnych chorób. Zdrowie to nie tylko stan dobrego samopoczucia fizycznego ale również psychicznego. Zdrowie psychiczne zależy w dużym stopniu od komfortu życia, który może być zaburzony przez różnorodne czynniki środowiskowe takie jak hałas. Ważnym elementem walki z hałasem jest jak najefektywniejsza ochrona ludności poprzez unikanie źródeł hałasu oraz jego zmniejszanie. Może to być realizowane poprzez wprowadzanie nowych rozwiązań technicznych oraz nowych technologii w tym urządzeń emitujących mniej hałasu. Ważnym elementem jest również edukacja społeczeństwa oraz wpływanie na zmianę indywidualnych i zbiorowych zachowań, które mogą przyczynić się do ograniczenia czynnika szkodliwego jakim jest hałas w życiu człowieka i zminimalizować pochodzące od niego negatywne skutki zdrowotne.

Słowa kluczowe: dźwięk, hałas środowiskowy, aspekty zdrowotne

\section{SOUND}

An acoustic wave (one of mechanical waves) is a disturbance that propagates in an elastic medium (e.g. in air, water or metal). Disturbances cause temporary changes in the density of a medium through which they are passing. This leads to local changes in the pressure of the medium. The propagation speed of a sound wave depends on the type of medium. In air, the speed is approx. $340 \mathrm{~m} / \mathrm{s}$, in water - approx. $1500 \mathrm{~m} / \mathrm{s}$, in iron $5100 \mathrm{~m} / \mathrm{s}($ rubber $-17-30 \mathrm{~m} / \mathrm{s}$, diamond $-18000 \mathrm{~m} / \mathrm{s}$ ).
The speed of sound in a medium depends not only on the density but also on the coefficient of stiffness:

$$
v=\sqrt{\frac{B}{\rho}}
$$

where:

$v$ - the speed of sound in a given medium [expressed in $\mathrm{m} / \mathrm{s}$;

$B$ - coefficient of stiffness [expressed in Pa];

$\rho$ - the density of a medium in which the sound wave is propagating $\left[\mathrm{kg} / \mathrm{m}^{2}\right]$.

Corresponding author: Andrzej Magiera, National Institute of Public Health - National Institute of Hygiene, Department of Environmental Health and Safety, 24 Chocimska str., 00-791 Warsaw, Poland, tel. +48 22 542123, e-mail: amagiera@pzh.gov.pl

(C) Copyright by the National Institute of Public Health - National Institute of Hygiene 
The coefficient of stiffness for water is about 10,000 times greater than for air, therefore the speed of sound is higher in water than in air. For a given material medium, the speed of sound propagation in it is constant (under certain conditions, for example at a certain temperature, salinity or humidity).

Acoustic waves cause audible sensations - sounds. Sounds belong to transverse waves - the particles of a medium oscillate in the direction of the wave propagation. They affect the hearing organ. Wave frequencies which elicit an auditory percept in humans range from about $16 \mathrm{~Hz}$ to about $20 \mathrm{kHz}$ (the amplitude of sound pressure level from $2 \cdot 10^{-5} \mathrm{~Pa}$ to $20 \mathrm{~Pa}$ ). Based on their frequency, sounds are divided into:

- infrasounds (frequencies below $16 \mathrm{~Hz}$, inaudible to most humans);

- audible sounds (frequencies from about $16 \mathrm{~Hz}$ to about $20 \mathrm{kHz}$ );

- ultrasounds (frequencies above $20 \mathrm{kHz}$, inaudible to most humans).

Sound features include:

- pitch, which depends on the frequency (the higher the frequency, the higher is the pitch);

- loudness, which depends on sound intensity;

- timbre.
Sound loudness depends on sound intensity (it is proportional to the decimal logarithm of sound intensity - ten times stronger sound intensity means twice the loudness). Logarithmic scale is used to determine the loudness of a sound. Sound intensity level is defined by the following formula:

$$
K=\log \frac{I}{I_{0}}[\mathrm{~B}]
$$

where:

$I$ - sound intensity;

$I_{0}$ - reference sound intensity - a sound intensity value corresponding to the threshold of human hearing $\left(I_{0}=10^{-12} \mathrm{~W} / \mathrm{m}^{2}\right)$.

Sound intensity level is expressed in bels (B). Due to the fact that bels (B) are too large, the decibel (dB) unit has been adopted (decibels are ten times smaller). Sound intensity level in decibels takes the following form:

$$
L=10 \log \frac{I}{I_{0}}[\mathrm{~dB}]
$$

Examples of sound intensity and sound intensity levels are shown in Table 1.

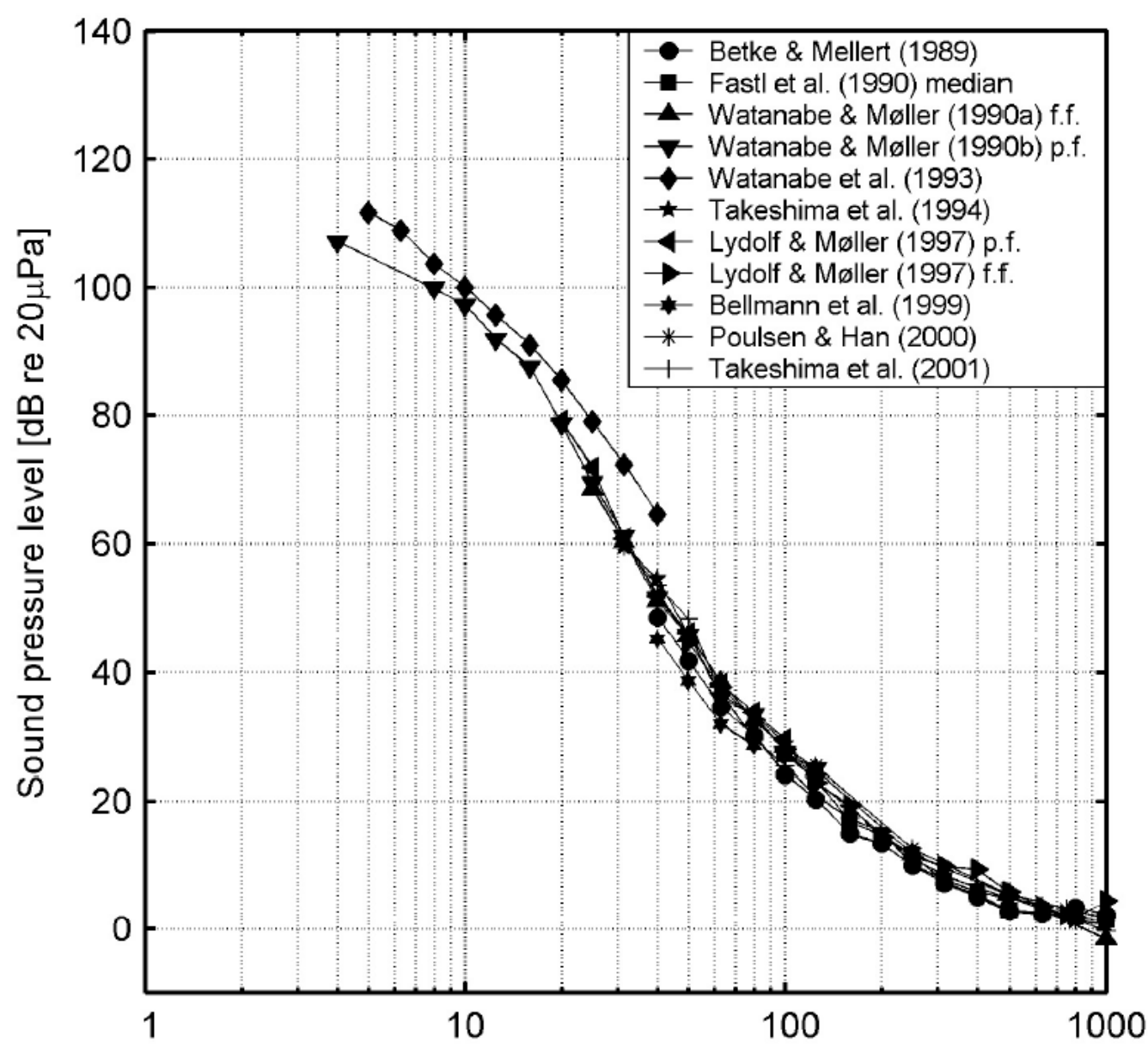

Figure 1. Hearing thresholds for low frequencies measured by various tests in 1989-2001 [20] 
Table 1. Examples of sound intensity and sound intensity levels

\begin{tabular}{|l|c|c|}
\hline \multicolumn{1}{|c|}{ Sound source } & $\begin{array}{c}\text { Sound } \\
\text { intensity I } \\
{\left[\mathrm{W} / \mathrm{m}^{2}\right]}\end{array}$ & $\begin{array}{c}\text { Sound } \\
\text { intensity } \\
\text { level L } \\
{[\mathrm{dB}]}\end{array}$ \\
\hline Hearing threshold / whisper & $10^{-12}$ & 0 \\
\hline Conversation & $10^{-8}$ & 40 \\
\hline Scream & $10^{-5}$ & 70 \\
\hline Pain threshold & $10^{0}$ & 120 \\
\hline
\end{tabular}

There is no lower frequency limit at which a person cannot hear sounds. Along with decreasing frequency, human hearing registers sounds to an increasingly lower extent. Below $20 \mathrm{~Hz}$ (infrasound), human hearing can also register sounds. Below this frequency, the sounds sense by the human ear appear discontinuous. Below $10 \mathrm{~Hz}$, pressure is felt in the ears. At sound levels above $20-25 \mathrm{~dB}$ with a frequency of $10 \mathrm{~Hz}$, vibration may be sensed in some (lower) parts of the body (the posterior side of the body - loins, buttocks, thighs and calves). There may be a feeling of pressure in the upper parts of the body. Hearing levels for men and women are the same. These levels drop after the age of 50. There is evidence that humans can be particularly sensitive to certain sound frequency bands. Therefore, it may happen that these people are hypersensitive to noise levels well below permissible (limit) values [20]. Figure 1 shows hearing thresholds for low frequencies measured by various tests in the years 1989-2001.

\section{NOISE AND ITS TYPES}

Evolution has shaped the perception of noise as a health hazard in human consciousness. Noise defined as undesirable sound is an environmental pollutant and cannot be neglected. People can get used to noise, but it is an individual matter. Adverse health effects can be observed when noise is continuous and exceeds certain established levels. Occupational noise is the most studied type of noise. In recent years, other types of noise have been investigated to an increasingly larger extent, including environmental noise: road traffic noise, railway traffic noise, air traffic noise, or industrial noise. These types of noise are associated with adverse health effects unrelated to the hearing organ. These include irritation, sleep disorders, cardiovascular diseases or cognitive impairment in children [2].

Noise is a major source of pollution not only for human physiology but also for the environment. According to the World Health Organization, exposure to noise levels exceeding $70 \mathrm{~dB}$ (A) for more than 24 hours has a negative impact on human health, causing a number of irreversible health effects, including hearing impairment. Such noise can cause anxiety to people living in its vicinity. Numerous studies prove that negative health effects occur in humans when the permissible noise levels are exceeded (e.g. increased blood pressure, sleep disturbances, increased anxiety). The main source of environmental noise is road traffic. Research shows that the road traffic noise levels depend on the type of surface (for asphalt it is lower, for concrete it is higher by about $6 \mathrm{~dB}(\mathrm{~A}))[16]$.

Directive 2002/49/EC of the European Parliament and of the Council of 25 June 2002 relating to the assessment and management of environmental noise introduces indicators assessing exposure to noise throughout the year:

- $\mathrm{L}_{\mathrm{den}}$ - day-evening-night noise indicator for overall annoyance, marked in Polish legal acts as $\mathrm{L}_{\mathrm{DWN}}$;

- $\mathrm{L}_{\mathrm{day}}$ - day-noise indicator for annoyance during the day period; the A-weighted long-term average sound level as defined in ISO 1996-2: 1987, determined over all the day periods of a year (time range from 6:00 a.m. to 6:00 p.m. in Poland), marked in Polish legal acts as $\mathrm{L}_{\mathrm{D}}$;

- $\mathrm{L}_{\text {evening }}-$ evening-noise indicator for annoyance during the evening period; the A-weighted longterm average sound level as defined in ISO 1996-2: 1987, determined over all the evening periods of a year (time range from 6:00 p.m. to 10:00 p.m. in Poland), marked in Polish legal acts as $\mathrm{L}_{\mathrm{w}}$;

- $\mathrm{L}_{\text {night }}$ - night-noise indicator for sleep disturbance; the A-weighted long-term average sound level as defined in ISO 1996-2: 1987, determined over all the night periods of a year (time range from 10:00 p.m. to 6:00 a.m. in Poland), marked in Polish legal acts as $\mathrm{L}_{\mathrm{N}}[6,26]$.

Two of them are applied in the Regulation of the Minister of the Environment of 14 June 2007 on permissible levels of noise in the environment $-\mathrm{L}_{\text {den }}$ $\left(\mathrm{L}_{\mathrm{DWN}}\right)$ and $\mathrm{L}_{\text {night }}\left(\mathrm{L}_{\mathrm{N}}\right)$. Indicators have been introduced to determine the exposure to noise during one day:

- $\mathrm{L}_{\text {Aeq D }}$ - the A-weighted equivalent continuous sound level measured during daytime (time range from 6:00 a.m. to 10:00 p.m.);

- $\mathrm{L}_{\text {Aeq } \mathrm{N}}$ - the A-weighted equivalent continuous sound level measured at night (time range from 10:00 p.m. to 6:00 a.m.) [24, 26].

The limitations related to the values of sound intensity (noise) are separate for workplaces and places of permanent residence of people (e.g. residential buildings). This is mainly due to the dwell time. When it comes to workplaces, it is usually 8 hours a day. Working people are healthy. At places where people live, this time is much longer - exposure may be 24 hours a day. It turns out that sensitivity and tolerance to noise differ depending on the time of day (in the evening and at night tolerance is lower). 
There are differences in defining environmental noise. World Health Organization defines environmental noise as noise generated by all sources except workplace noise [2]. Directive 2002/49/EC of the European Parliament and of the Council of 25 June 2002 relating to the assessment and management of environmental noise contains a more detailed definition of environmental noise. According to this Directive, environmental noise means undesirable or harmful sounds caused by human activity in the open air, including noise generated by means of transport, road traffic, railway traffic, air traffic, and noise originating from industrial activities [21].

Noise spreads in the environment, especially in highly urbanized places. It is associated with industrial development, transport and progressive urbanization. In the European Union, by 2014, about 56 million people living in areas of more than 250,000 inhabitants (more than half of the population) were exposed to road traffic noise exceeding $\mathrm{L}_{\text {den }} 55 \mathrm{~dB}$, which poses a health risk [2]. At the end of 2019, it was estimated that around 82 million people were exposed to road traffic noise levels of at least $55 \mathrm{~dB}$ throughout the day in urban areas. The number of people exposed to road traffic noise outside urban areas is 31 million. When it comes to nighttime noise, the figures are 57 million and 21 million, respectively. This means that at least $20 \%$ of the population is exposed to high levels of road noise during the whole day and $15 \%$ at night [8].

The second source of environmental noise in Europe is railway traffic noise. It is currently estimated that almost 22 million people are exposed to this type of noise exceeding $55 \mathrm{~dB}$ throughout the day 11 million people are exposed to railway traffic noise in urban areas, while the other half outside urban areas. About 9 million people are exposed to railway traffic noise exceeding $50 \mathrm{~dB}$ in urban areas at night, while 8 million people outside urban areas. It is estimated that about $4 \%$ of the population is exposed to railway noise above the limit values throughout the day, and $3 \%$ of the population at night [8].

According to the aforementioned Directive of the European Parliament, air traffic noise is defined as noise caused by aircraft landings and take-offs in areas surrounding airports. Therefore, aviation noise affects a much smaller proportion of the population than road or railway noise. It is estimated that about 3 million people are exposed to air traffic noise in excess of $55 \mathrm{~dB}$ throughout the day in urban areas; outside urban areas - about 1 million. As for nighttime noise, the figures are 1 and 0.5 million for urban and outside urban areas, respectively. These values represent a small percentage of the total European population. However, aircraft noise is an important source of noise, as it is considered more annoying than road or railway traffic noise [8].
Another type of environmental noise, industrial noise, is the least significant one, which affects human health to the lowest extent. It is estimated that about 800,000 people living in urban areas are exposed to this type of noise exceeding $55 \mathrm{~dB}$ throughout the day and approximately 400,000 people are exposed to industrial noise exceeding $50 \mathrm{~dB}$ at night. Industrial noise affects $0.15 \%$ of the population in urban areas throughout the day and $0.08 \%$ of the population at night [8].

Prolonged environmental noise causes around 12,000 premature deaths a year in Europe and contributes to around 48,000 cases of ischemic heart disease. 22 million people suffer from chronic high annoyance and 6.5 million people suffer from severe sleep problems. Due to the air traffic noise, 12,500 school-aged children experience learning difficulties [8].

\section{WEIGHTING CURVES}

In order to bring the noise measurement results closer to the actual auditory sensation, taking into account the physiological sensitivity of the human ear (e.g. A-weighting curve), weighting filters were introduced. Literature and legal acts use $\mathrm{dB}(\mathrm{A})$ as the unit of sound intensity. This unit takes into account the subjective human perception of loudness and the sensitivity of the human ear to low frequency sounds. In this case - the so-called A-weighting curve. The shape of the A-weighting curve better defines the audibility of a given signal. The following weighting curves are used for different sound level values:

- A-weighting curve - for sound levels from 0 to $55 \mathrm{~dB}$ (used for soft sounds, the most consistent with the sensitivity of the human ear; World Health Organization considers the curve inadequate for low-frequency noise, including infrasound. Noise in this range is underestimated, cut below a certain frequency - about $10 \mathrm{~Hz}$ );

- B-weighting curve - for sound levels from 55 to $85 \mathrm{~dB}$;

- C-weighting curve - for sound levels above $85 \mathrm{~dB}$;

- D-weighting curve - for air traffic noise measurements.

The weighting curves are shown in Figure 2 and Figure 3.

In the case of the G-weighting curve, it is suitable for infrasounds only; it strongly cuts the range of low frequencies (over $100 \mathrm{~Hz}$ ), not including the audible range. $\mathrm{C}$-weighting curve below the $10 \mathrm{~Hz}$ frequency value is similar to the G-weighting curve - it does not cut low frequencies. For higher frequencies, it acts as the A-weighting curve (the best solution when the noise contains audible and low-frequency components, including infrasound). 




Figure 2. Weighting curves [18]



Figure 3. Weighting curves [22, 23]

\section{HEALTH EFFECTS OF NOISE}

Noise as undesirable sound is the main cause of hearing loss. It can be caused by a single exposure to a high-intensity sound (e.g. a gun shot or explosion) or by prolonged exposure to a less loud noise (greater than 75-85 dB), e.g. environmental noise. Exposure to continuous noise throughout one's life can lead to progressive hearing loss and increased hearing sensitivity threshold. Hearing damage caused by noise is a direct consequence of the impact of sound energy on the inner ear [25]. Noise-induced hearing loss is caused by the loss of the cochlear auditory cells - an anatomical part of the inner ear of mammals that is unable to regenerate [2].
Previous studies on the impact of noise on humans have shown that the harmfulness of noise depends primarily on its intensity level and is modified by such factors as frequency composition (noise at higher frequencies is more harmful, but noise at lower frequencies is more burdensome), variability over time (as time goes on, receptors lose their sensitivity to constant stimuli, but react to changes in stimulus parameters), and character (noise with tonal components and impulses is more bothersome than noise without such elements) $[21,25]$.

The noise emitted by wind turbines is quite specific. Low-frequency noise $(100-500 \mathrm{~Hz})$ constitutes a large share. In this range of frequencies the time generated by the turbines exceeds the hearing threshold. This type of noise is very specific - it has a modulated amplitude which is perceived by people as whistling or pulsating. High-frequency noise is more harmful, however low-frequency noise is more bothersome. The variation of noise coming from wind turbines in time further increases the annoyance. For humans the noise from wind turbines is more annoying (due to its specificity) than other types of noise (e.g. traffic noise) with the same sound intensity levels. Large wind turbines emit much more low frequency noise than small ones. The sounds generated by wind turbines come from the rotating mechanical parts of the turbine and the aerodynamic noise produced by the blades (interaction with air). The mechanical sounds of the rotating elements create a tonal and modulated noise. In modern wind turbines, these effects are minimized (due to technical progress) [4]. Permissible noise levels from wind turbines have been introduced in many countries around the world. Many countries have enacted legal regulations in which noise levels from wind turbines must not exceed $35-40 \mathrm{~dB}$ (A) or $5 \mathrm{~dB}$ (A) above the background noise level (including Australia, France or England) [3]. There are no separate guidelines in Polish legal acts limiting noise from wind turbines in the environment (limit values). This noise is treated as audible noise (subject to the same restrictions).

In many countries, no attention is paid to environmental pollution caused by noise. Noise protection policies should take into account the most effective protection of the population through, inter alia, proper planning of residential building construction, new technologies and devices generating sounds of much lower intensity, insulation of residential buildings (soundproof screens, appropriate window glass) [1].

Environmental noise includes all unwanted sounds except those from the working environment. Environmental noise pollution, a form of air pollution, constitutes a threat to health and well-being. The noise is more acute and widespread than ever before 
and will continue to increase due to population growth, urbanization, and the associated increase in noise sources. The increase in environmental noise is caused by increased road, railway and air traffic. Noise causes direct and cumulative adverse effects on health, causing real (economic) and non-material losses (e.g. well-being), disturbing sleep, concentration, communication, and recreation $[10,12,13]$.

The evidence for the health effects of environmental noise is strongest with regard to irritation, sleep, and cognition in adults and children. Exposure to noise in the workplace is also somewhat associated with raised blood pressure. The effects of noise contribute to the deterioration of the quality of life more than having a direct impact on the development of the disease. The risk of developing a mental or physical illness related to environmental noise is low but likely. People can develop strategies to deal with noise exposure if they cannot eliminate it from the environment by moving away from its source. Noise might also be more harmful to health in situations where several stressors are affected simultaneously. The mechanisms of adaptation to long-term noise exposure require further research in this area. While there may be some adaptation to noise-induced sleep disturbance, habituation is not complete, especially in terms of heart rate. Most people exposed to chronic noise (e.g. air traffic noise) can tolerate it. However, surveys suggest that the high level of irritation does not decrease with time [25].

It is widely believed that noise interferes with communication and interferes with various human activities, causing irritation. In some cases, annoyance can lead to stress, followed by symptoms and illness. Noise can also have a direct effect on health (not through annoyance). The most common and well documented subjective response to noise is irritation, which can include fear and anger. In both road traffic noise and air traffic noise studies, it was found that noise level is a nuisance depending on the degree of exposure. Air traffic noise is most disruptive to talking, watching TV or listening to the radio, while road traffic noise, if it occurs at night, is most likely to affect sleep [25]. Disturbed sleep, in turn, may contribute to the occurrence of other negative health effects, e.g. it activates the body's response to stress [1]. This is evidenced by research on the impact of noise on animals conducted in Poland. One study of 40 geese at different distances from a wind turbine $(50$ and 500 meters) looked at the blood levels of cortisol (an organic chemical substance produced by the cortex of the adrenal gland, also known as the stress hormone). During the above experiment, noise from wind turbines was measured. As the distance to the wind turbine increased (distance to the noise source), blood cortisol levels decreased. The level of cortisol increased with the increasing exposure of animals to noise [19]. These results are in line with other animal studies that indicate a negative effect of noise on animals. The proximity to the noise source may also contribute to the deterioration of the meat quality of farmed animals [13].

Extremely intense exposure to noise near the pain threshold causes increased secretion of cortisol from the adrenal cortex, while exposure to noise at levels from 90 to $100 \mathrm{~dB}$ (A) increases catecholamine (including adrenaline, noradrenaline and dopamine) [12]. Adrenaline is a hormone that regulates blood circulation. Noradrenaline mobilizes the brain and body to act. Its production is the lowest during sleep. It reaches high levels in stressful and distress situations (fight-or-flight response). In the brain, norepinephrine increases agitation and alertness but also anxiety and fear, the excess of which leads to anxiety disorders. In the rest of the body, noradrenaline increases heart rate and blood pressure. If activities such as conversation or recreation are disturbed by environmental noise exceeding the sound level Leq $=60 \mathrm{~dB}(\mathrm{~A})$, there is also an increase in catecholamine. Road traffic noise at night above the sound level equivalent of Leq $=30 \mathrm{~dB}(\mathrm{~A})$ and the maximum level Lmax $=55 \mathrm{~dB}(\mathrm{~A})$ causes a significant, sharp elevation of cortisol, which transforms into a chronic increase when exposure to noise is repeated. In parallel to higher cortisol levels, a chronic increase in noradrenaline is also observed [12].

Environmental noise also causes sleep problems. These problems can lead to endocrine and metabolic perturbations as well as cardiovascular and psychiatric disorders in adults and children. During the day, people who are under the influence of environmental noise struggle with sleepiness, fatigue, irritation and mood changes [11]. Exposure to noise while sleeping can increase blood pressure, heart rate and body movement. Disturbed sleep may also have its adverse effects during the day. Research on noise reduction shows that by reducing noise, one can increase the amount of REM sleep (rapid eye movement sleep) and slow wave sleep. The amount of slow wave sleep, during which the body rests, is particularly important for human health. Metabolism is significantly reduced, blood pressure drops, breathing and heart rate slow down, the kidneys produce less urine, and food moves more slowly through the intestines. During this phase of sleep, hormones (such as the growth hormone) are released, cortisol (the stress hormone) levels are inhibited, glucose levels and cardiovascular functions are regulated. Experimental studies have shown that both sleep restriction and poor sleep quality also disturb the appetite and affect the immune processes [11]. 
Research also reveals a strong association between noise exposure and cardiovascular disorders such as arterial hypertension, and the risk of myocardial infarction and stroke (which can also be caused by hypertension). Exposure to noise disrupts sleep, which in turn causes chronic and more serious health problems. In addition, noise activates the body's stress response, which consequently initiates a number of other reactions in the body, mainly negative ones. The long-term effect of noise on stress hormones may be a mechanism that adversely affects the cardiovascular system [1].

The problem of coping with stress in children is much more serious than in adults. Childhood mental health problems can have long-term consequences in later school years and in the professional career. A study conducted by Lim et al. in 2018 found a corelation between noise sensitivity and emotions or behavior among children and adolescents. The research has shown that noise sensitivity has a worse impact on the mental health of children and adolescents in the low-income group. The relationship between noise sensitivity and problems was much smaller in the high-income research group [17].

\section{SUMMARY}

Noise can cause a number of negative effects on health that directly or indirectly affect humans. The occurrence of some negative and harmful health effects leads to others and may contribute to the development of various diseases $[12,13]$. World Health Organization defines health as a state of complete physical, mental and social well-being and not merely the absence of disease or infirmity. This definition has not been changed by World Health Organization since 1948 [5]. Health is not only observable physical symptoms (biomedical model) or functional human activity (socio-medical model). A very important element of health is the dimension of mental experiences [7]. Mental health depends to a large extent on the quality of life (avoiding stress, getting enough sleep), which can be disturbed by factors such as noise. Therefore, an important element of noise protection policy is the most effective protection of the population through (if possible) avoiding sources of noise and reducing it. This can be achieved by introducing new technical solutions and new technologies, including devices that generate less noise, the use of protection of residential buildings through soundproof screens, properly insulating windows or building materials, using appropriate surfaces, car engines that emit less noise, or appropriate tires. A very important aspect of fighting excessive noise is also educating the society and influencing the change of individual and collective behavior (listening to music through earphones, excessive sound level during recreation - at concerts, in cinema halls, during broadcasting of commercials on TV, and even in schools during breaks). These activities can effectively contribute to limiting the harmful factor, which is noise in human life, and minimize the resulting adverse health effects.

\section{Conflict of interest}

The authors declare no conflict of interest.

\section{Acknowledgements}

This work was financially supported by the National Institute of Public Health-National Institute of Hygiene in Warsaw, Poland, in the frame of project No BK-1/2020.

\section{REFERENCES}

1. Aluko E. O., Nna V.: Impact of Noise Pollution on Human Cardiovascular System, International Journal of TROPICAL DISEASE \& Health 6(2):35-43, doi: 10.9734/IJTDH/2015/13791

2. Basner M., Babisch W., Davis A., Brink M., Clark C., Janssen S., Stansfeld S.: Auditory and non- auditory effects of noise on health 2014, 383(9925) 1325-1332, doi: 10.1016/S0140-6736(13)61613-X

3. Berger R. G., Ashtiani P., Ollson C. A., Whitfield Aslund M., McCallum L. C., Leventhall G., Knopper L.D.: Health-based audible noise guidelines account for infrasound and low-frequency noise produced by wind turbines, Front Public Health. 2015 Feb 24; 3:31. doi: 10.3389/fpubh.2015.00031

4. Bolin K., Bluhm G., Eriksson G., Nilsson M.: Infrasound and Low Frequency Noise from Wind Turbines: Exposure and Health Effects, Environmental Research Letters. 2011 6(3):035103, doi: 10.1088/17489326/6/3/035103

5. Constitution of the World Health Organization, Am J Public Health Nations Health 1946 Nov; 36(11): 131523, doi: 10.2105/ajph.36.11.1315.

6. Directive 2002/49/EC of the European Parliament and of the Council of 25 June 2002 relating to the assessment and management of environmental noise - Declaration by the Commission in the Conciliation Committee on the Directive relating to the assessment and management of environmental noise

7. Domaradzki J.: O definicjach zdrowia i choroby, Folia Medica Lodziensia, 2013, 40/1:5-29. Available: http://yadda.icm.edu.pl/yadda/element/bwmeta1. element.psjd-277d7478-0030-47a4-b518-3ecc6fa630b9/ c/O_definicjach_zdrowia_i_choroby.pdf (Accessed 15.10.2020)

8. EEA Report No 22/2019 Environmental noise in Europe - 2020. Available https://www.eea.europa. eu/publications/environmental-noise-in-europe/at download/file (Accessed 11.09.2020)

9. Farboud A., Crunkhorn R., Trinidade A: Wind turbine syndrome: Fact or fiction?, The Journal of 
laryngology and otology 2013, 127(3):1-5. doi: 10.1017/ S0022215112002964.

10. Goines L., Hagler L.: Noise Pollution: A Modern Plague, Southern Medical Journal 100(3):287-94, doi: 10.1097/SMJ.0b013e3180318be5

11. Halperin D.: Environmental noise and sleep disturbances: A threat to health?, Sleep Science 7(4):209-212, doi: 10.1016/j.slsci.2014.11.003

12.Ising H., Braun C.: Acute and chronic endocrine effects of noise: Review of the research conducted at the Institute for Water, Soil and Air Hygiene, Noise and Health 2000; 2(7):7-24. Available: https:// www.researchgate.net/profile/Hartmut_Ising/ publication/10810988_Acute_and_chronic_endocrine_ effects of noise Review of the research conducted_at_the_Institute_for_Water_Soil_and_Air_ Hygiene/links/55c4f9e408aeca747d6183d5/Acute-andchronic-endocrine-effects-of-noise-Review-of-theresearch-conducted-at-the-Institute-for-Water-Soiland-Air-Hygiene.pdf (Accessed 15.10.2020)

13. Karwowska M., Mikolajczak J., Dolatowski Z.J., Borowski S.: The effect of varying distances from the wind turbine on meat quality of growing-finishing pigs, Ann. Anim. Sci., Vol. 15, No. 4 (2015) 1043-1054, doi: 10.1515/aoas-2015-0051

14. Koszarny Z:: Ocena stanu zdrowia i samopoczucia ludności zamieszkałej w zróżnicowanych warunkach akustycznych, Rocz Panstw Zakl Hig 2001, 52(2): 165178, Available: http://wydawnictwa.pzh.gov.pl/roczniki pzh/pobierz-artykul?id=222 (Accessed 27.01.2020)

15. Koszarny Z.: Wpływ intensywnego hałasu ulicznego na samopoczucie i samoocenę stanu zdrowia mieszkańców, Rocz Panstw Zakl Hig 2000, 51(2): 191-201, Available: http://wydawnictwa.pzh.gov.pl/roczniki_pzh/pobierzartykul?id=320 (Accessed 27.01.2020)

16. Li Q., Qiao F., Yu L., Shi J.: Modeling vehicle interior noise exposure dose on freeways: Considering weaving segment designs and engine operation, J Air Waste Manag Assoc. 2018 Jun; 68(6): 576-587, doi: 10.1080/10962247.2017.1350213

17. Lim J., Kweon K., Kim H. W., Cho S. W., Park J., Sim C.S.: Negative impact of noise and noise sensitivity on mental health in childhood, Noise Health 2018 Sep-Oct; 20(96): 199-211, doi: 10.4103/nah.NAH_918

18. Merska O., Mieczkowski P., Żymetka D.: Low-noise thin surface course - evaluation of the effectiveness of noise reduction, Transportation Research Procedia 2016, 14 2688-2697, doi: 10.1016/j.trpro.2016.05.445

19. Mikołajczak J., Borowski S., Marć-Pieńkowska J., Odrowąz-Sypniewska G., Bernacki Z., Siódmiak J.,
Szterk P.: Preliminary studies on the reaction of growing geese (Anseranser $\mathrm{f}$. domestica) to the proximity of wind turbines, Pol J Vet Sci. 2013;16(4):679-86, doi: 10.2478/pjvs-2013-0096

20.Moller H., Pedersen C. S.: Hearing at low and infrasonic frequencies. Noise Health 2004; 6(23):3757. Accessed: https://last.hit.bme.hu/download/AOAB/ Infrahang irodalom/Hearing $\% 20$ at $\% 2010$ w $\% 20$ and $\% 20 \mathrm{infrasonic} \% 20$ frequencies $\% 20$ Moller $\% 20$ H,\%20Pedersen\%20C\%20S\%20-\%20Noise \%20Health. htm (Accessed 15.10.2020)

21. Pawlas K:: Hałas jako czynnik zanieczyszczający środowisko - aspekty medyczne, Med Srod. 2015;18(4):49-56. Available: http://psjd.icm.edu.pl/psjd/ element/bwmeta1.element.psjd-0452173c-fc76-4e10b9f3-f8b88f3bad44/c/MS 2015-4 07.pdf-1 (Accessed 15.10.2020)

22.Pawlas K., Pawlas N., Boron M., Szłapa P., Zachara $J$ : Przegląd kryteriów oceny infradźwięków i hałasu niskoczęstotliwościowego $\mathrm{w}$ środowisku zawodowym i pozazawodowym, Medycyna Środowiskowa Environmental Medicine 2013, 16(1) 1-8. Available: https://www.researchgate.net/publication/236117937 Pawlas_K_Pawlas_N_Boron_M_Szlapa_P_Zachara J Przeglad_kryteriow_oceny_infradzwiekow_i halasu_niskoczestotliwosciowego_w_srodowisku_ zawodowym_i_pozazawodowym_Medycyna_ Srodowiskowa - Ernvironmental Medi/ link/546da9710cf2193b94c592bl/download (Accessed 15.10.2020)

23. Romański L., Bieniek J., Bukowski P., Kobel P.: The Impact of Infrasounds Generated by Wind Power Stations on a Human Being, Agricultural Engineering 2016, 20 (1) 155-156, doi: 10.1515/agriceng-2016-0016

24. Rozporządzenie Ministra Środowiska z dnia 14 czerwca 2007 r. w sprawie dopuszczalnych poziomów hałasu w środowisku (t.j. Dz. U z 2014 r., poz. 112) [Regulation of the Minister of The Environment of 14 June 2007 on permissible levels of noise in the environment (Journal of Laws of 2014, item 112)]

25.Stansfeld S. A., Matheson M.P.: Noise pollution: Nonauditory effects on health, British Medical Bulletin 68(1):243-57, doi: 10.1093/bmb/ldg033

26. Ustawa $\mathrm{z}$ dnia 27 kwietnia $2001 \mathrm{r}$. Prawo ochrony środowiska. Dz. U. 2020 r. poz. 1219) [Act of 27 April 2001, Environmental Protection Law], Journal of Laws of 2020, item 1219)].

Received: 24.11.2020

Accepted: 04.02.2021 